\title{
MAPPING THE CONSUMERS COFFEE POWDER MANGSI COFFEE BASED ON SEGMENTING, TARGETING, AND POSITIONING IN DENPASAR CITY
}

\author{
I Putu Agi Pratama, Ratna Komala Dewi and Ni Putu Artini \\ Agribusiness Study Program, Agriculture Faculty, Udayana University, Jl. PB. Sudirman Denpasar, \\ 80223, Bali, Indonesia \\ Correspondence Email: agipratama02@gmail.com
}

Submitted_29 June 2020; Accepted 2 December 2020

\begin{abstract}
ABSTRAK
Tidak semua pelanggan dapat dilayani oleh perusahaan. Setiap perusahaan perlu mengidentifikasi segmen pasar yang dapat dilayani secara efektif dengan cara membedakan segmensegmen pasar utama, membidik satu atau dua segmen dan mengembangkan produk sehingga selalu ada terobosan baru. Suatu perusahaan agar dapat unggul dalam persaingan harus mampu mengenali segmen pasarnya, target pasar serta posisi produk terhadap pesaingnya. Penelitian ini bertujuan untuk mengetahui segmenting, targeting, dan positioning kopi bubuk Mangsi Coffee. Teknik penentuan sampel yang dipergunakan adalah dengan metode nonprobability sampling yaitu accidential sampling sebanyak 60 responden. Segmenting dan targeting dilakukan dengan menggunakan analisis crosstab, sedangkan positioning menggunakan analisis multi dimensional scaling dan correspondence analysis. Segmentasi pasar kopi bubuk Mangsi Coffee berdasarkan karakteristik konsumen adalah laki-laki yang berusia dewasa, berjenjang pendidikan tinggi (pendidikan terakhir), berprofesi sebagai pegawai dengan pengeluaran perbulan diatas UMK Kota Denpasar tahun 2019 (Rp 2.553.000,00). Konsumen Mangsi Coffee berdasarkan segmentasi psikografis cenderung memilih produk yang berkualitas dan menjadikan kebiasaan mengkonsumsi kopi sebagai trend dan gaya hidup sedangkan konsumen Mangsi Coffee berdasarkan segmentasi perilaku konsumen cenderung memilih produk sesuai manfaat. Positioning dengan menggunakan analisis multi dimensional scalling (MDS) menunjukan bahwa, kopi bubuk Mangsi Coffee tidak berada dalam satu kuadran dengan ketiga produk pesaingnya. Peta menunjukan keempat produk berada dalam kuadran yang berbeda. Analisis CA (correspondence analysis), menunjukan keunggulan produk kopi bubuk Mangsi Coffee apabila dibandingkan dengan produk pesaingnya adalah atribut dalam hal kemasan. Pentingnya perusahaan memperhatikan segmenting, targeting, dan positioning untuk dapat fokus mencapai tujuan perusahaan dan bertahan dalam persaingan pasar yang ketat. Strategi peningkatan penjualan dilakukan dengan menyesuaikan hasil kajian dalam penelitian dan kondisi perusahaan Mangsi Coffee sehingga dapat mengambil kebijakan yang sesai tujuan perusahaan.
\end{abstract}

Kata kunci: bubuk kopi, positioning, segmenting, targeting

\begin{abstract}
Not all customers can be served by the company. Each company needs to identify market segments that can be served effectively by differentiating the main market segments, aiming at one or two segments and developing products so that there are always new breakthroughs. A company in order to excel in competition must be able to recognize its market segment, target and product position against its competitors. This research aims to determine the segmenting, targeting, and positioning of Mangsi Coffee powder. The sampling technique used is the nonprobability sampling method that is accidential sampling. Segmenting and targeting is done by using crosstab analysis, while positioning uses multi dimensional scaling analysis and correspondence analysis. Mangsi Coffee powder market segmentation based on the characteristics of consumers are men who are adults, graduated from tertiary education
\end{abstract}


(last education), work as employees with monthly expenditure above the Denpasar City UMK in 2019 (Rp. 2,553,000.00). Mangsi Coffee consumers based on psychographic segmentation tend to choose quality products and make coffee consumption habits a trend and lifestyle while Mangsi Coffee consumers based on segmentation of consumer behavior tend to choose products according to their benefits. Positioning using multi-dimensional scaling analysis (MDS) shows that, Mangsi Coffee powder is not in one quadrant with all three competing products. The map shows that all four products are in different quadrants. CA analysis (correspondence analysis), shows the superiority of Mangsi Coffee powder products when compared with competitors' products is an attribute in terms of packaging. The importance of companies to pay attention to segmenting, targeting, and positioning to be able to focus on achieving company goals and survive in fierce market competition. The strategy to increase sales is carried out by adjusting the results of studies in research and the conditions of the Mangsi Coffee company so that it can take policies that are in accordance with company goals.

Keywords: coffee powder, positioning, segmenting, and targeting

\section{INTRODUCTION}

The rapid development of the business world has triggered increasingly fierce competition among entrepreneurs. Entrepreneurs who are quick to adapt will dominate the market and entrepreneurs who are unable to adapt will lose in market competition. Currently, there are many similar products (homogeneous) and diverse products (heterogeneous) in the market, so that entrepreneurs compete to attract the attention of consumers. Marketing is not only chasing a momentary big sale but marketing activities can also be carried out by knowing the desires of consumers. Marketing has an important role in a free market where every company competes to show the advantages of products to consumers (Dewi, 2017). The success of a company starts with product design (innovation) to differentiate its products from similar competitor products to maintain and increase sales. Product innovation is very important to run because the resulting product is vulnerable to consumer needs, wants and tastes (Lestari, 2017).

The development of the business world in this era of globalization affects all fields and sectors. The agricultural sector is included in the main sector of the business world because the agricultural sector provides production input in companies. The agricultural sub-sector which has an important role in the Indonesian economy is the plantation sub-sector, one of which is the coffee commodity. The success of coffee agribusiness requires the support of all parties involved in the production process to marketing coffee (Rahardjo, 2012). Coffee with average production growth of $1.03 \%$ in 2010-2014 is one of Indonesia's leading plantation commodities. The fluctuation in the volume of Indonesian coffee exports from 1980-2015 tended to increase with an average percentage of growth reaching $4.39 \%$ per year. In 1980, the export volume of Indonesian coffee was 238,677 tons with an export value of US $\$ 656,000,000$, then in 2015 , the export volume increased to 502,021 tons or the US $\$ 1,198,000$ million (Kementan, 2016).

Bali plays an important role in the coffee industry in Indonesia. Coffeeproducing areas in Bali are concentrated in two areas for Arabica coffee development, namely in Kintamani and robusta coffee development in Pupuan. Kintamani coffee, as a pioneer in obtaining a certificate of geographic indication for Indonesian agricultural products, is a Kintamani specialty Arabica coffee product (Ardana, 2017). Kintamani coffee has a taste with a regular level of sufficient acidity, a strong aroma quality and intensity, with an aroma of the citrus family (orange and lime flavor), and medium thickness (MPIG, 2007). Pupuan Robusta coffee is located in 14 villages in the Pupuan Sub-district with an altitude of 500900 masl. This coffee has a distinctive flavor, chocolate and caramel aroma, with a high level of a thickness (MPIG, 2016). 
Currently, various local brands that raise the potential of local Balinese coffee are increasing. This will add to the challenge of a company to be able to compete among businesses in the Bali coffee industry. One of the businesses that conduct marketing activities and are engaged in coffee is Mangsi Coffee. Mangsi Coffee focuses on developing ground coffee and café. The marketing coverage area of Mangsi Coffee ground coffee includes domestic markets of several large companies and minimarkets, including Indomaret throughout Bali and several souvenir markets in Bali. The owner of Mangsi Coffee realizes that not all customers can be served by the company. For a company to excel in competition, the company must be able to recognize its market segment, target market and product position against its competitors. This study aims to determine segmenting, targeting, positioning, and strategies to increase sales of Mangsi Coffee ground coffee. The difference between previous research and this research is the location of the study, the time of the study, the differences in the commodity/product used as research, and the analysis used for segmenting is the crosstab analysis.

\section{RESEARCH METHOD}

This research was started in early June 2019 until the end of July 2019, located at Mangsi Coffee on Jl. Merdeka no 99, Denpasar Timur Sub-District, Denpasar. The types of data used in this research are quantitative data and qualitative data. The data sources of this research are primary data and secondary data. Primary data is data obtained directly from key informants, namely the owner of Mangsi Coffee, $\mathrm{Mr}$ Windu Segara Senet and consumer respondents of Mangsi Coffee. Primary data obtained was information about the company and the results of the research questionnaire interview. Secondary data is data obtained indirectly from the source which can provide related information in research, namely; books, journals, online articles and information on government agencies related to research.

There are several methods used in collecting the research data, namely the collection of data obtained directly in the study including interviews conducted with the owner of the Mangsi Coffee business regarding research data, documentation, and observation. In addition, the data collection method is by distributing questionnaires to 60 customers of Mangsi Coffee products. Another method is library research, research conducted by reading library books, literature, and electronic media related to research.

The analysis used in this research is cross-tabulation analysis (crosstab), multidimensional scaling (MDS), and correspondence analysis (CA). Segmenting and targeting were carried out using crosstab analysis while positioning used multidimensional scaling and correspondence analysis.

\section{RESULT AND DISCUSSION}

\section{Market Segmentation of Mangsi Coffee Ground Coffee}

Market segmentation of Mangsi Coffee ground coffee is grouped based on gender, age, education, expenses and profession on psychographic variables and consumer behavior. According to Kotler (2001), psychographic segmentation is a grouping based on the characteristics of each consumer, such as class, motivation, personality, perceptions, interstices, interests, and attitudes. Buyer behavior segmentation is divided into groups based on their knowledge, attitudes, usage and responses to a product.

The crosstab results between sexes and psychographic variables show that both male and female have very good perceptions, namely male at $78.4 \%$ and female at $77.8 \%$. The number of male consumers who are more dominant with very good perceptions in the psychographic segmentation indicates that the Mangsi Coffee brand and products are trusted for daily consumption. The crosstab results between gender and consumer behavior show 
that both male and female have good perceptions, namely $74.5 \%$ of men and $66.7 \%$ of women. The number of men who are more dominant with good perceptions in the consumer behavior segmentation shows that Mangsi Coffee consumers tend to choose coffee products according to the benefits of the product. The benefits provided are the ease of consuming Mangsi Coffee with a separate sugar-filled package.

The crosstab results between age and psychographic variables show that between adolescents, adults, and the elderly in the psychographic segmentation both have very good perceptions, namely adolescents by $100 \%$, adults by $76 \%$, and elderly at $79.2 \%$. The number of adults is more dominant with good perceptions in the psychographic segmentation (lifestyle, interests and opinions) indicating that Mangsi Coffee consumers in adulthood tend to be lifestyleoriented. The pattern of consuming coffee in a coffee shop today is not just enjoying coffee but just hanging out and relaxing (Herlyana, 2012). The crosstab results between age and consumer behavior variables show that adults and elderly people in the consumer behavior segmentation both have a good perception, which is adults at $64.7 \%$ and seniors at $87.5 \%$. The number of adults is more dominant with good perceptions on consumer behavior segmentation (benefits, levels of use, and attitudes towards the product) shows that adult consumers of Mangsi Coffee consume Mangsi Coffee as many as 32 people seen from the data (52\%).

The crosstab results between education and psychographic variables show that consumers with secondary primary education and higher education have very good perceptions. The number of respondents with higher education (latest education) dominates very good perceptions in the psychographic segmentation. This shows that respondents with the latest diploma, undergraduate and postgraduate education have made drinking coffee a lifestyle. The results of the crosstab between education and consumer behavior variables show that the level of higher education is more dominant. The ratio shows a good perception at the primary-secondary education level (68.4\%) and the higher education level (75.6\%). The number of respondents with a higher education level is more dominant in having a good perception of consumer behavior segmentation, indicating that the level of use of Mangsi Coffee products is high.

The crosstab result between expenses and psychographic variables shows the ratio of consumers with very good perceptions, namely consumers who spend below/equal to the Regional Minimum Wage (87.5\%) and above the Regional Minimum Wage (76.9\%). The number of consumers spending per month above IDR 2,553,000.00 as many as 52 respondents in the psychographic segmentation showed that Mangsi Coffee consumers use part of their income to buy Mangsi Coffee products. Consumers in this category tend to consume coffee because it has become a daily necessity. The results of the crosstab between expenses and consumer behavior variables show that respondents with expenses below/equal to the Denpasar City Minimum Wage and respondents with expenses above the Denpasar City Minimum Wage have a good perception. The ratio shows that respondents have expenses below/equal to the Denpasar City Minimum Wage of $75.0 \%$ and respondents with expenses above the Denpasar Minimum Wage by $73.1 \%$. The number of respondents with expenses above IDR 2,553,000 was more dominant in having a good perception of consumer behavior segmentation, indicating that Mangsi Coffee consumers tend to choose coffee products according to the benefits of the product. The price of ground coffee Mangsi Coffee per 100 grams is IDR 22,500, which is more affordable for the uppermiddle-class compared to its competitor products, which range from IDR 10,000 IDR 15,000. Mangsi Coffee powder packaging has the advantage of providing separate sugar so that it provides superior benefits in the appetite for consuming Mangsi coffee products. 
The crosstab results between professions and psychographic variables showed very good perceptions, with a ratio of the student (84.6\%), employees $(79.2 \%)$, and professional staff $(73.9 \%)$. The number of respondents who work as employees dominates with very good perceptions on the psychographic segmentation showing the results that consumers with the employee profession are consumptive of Mangsi Coffee products. The results of the crosstab between the profession and the consumer behavior variable showed a good perception, with a ratio of students $(69.2 \%)$, employees $(62.5 \%)$, and professional staff $(87.0 \%)$. The number of respondents who work as employees dominates with good perceptions of consumer behavior segmentation showing the results that consumer who work as employees consume Mangsi Coffee products in carrying out their daily activities. According to Halodoc (2018), the benefits of drinking coffee before starting work can increase concentration, eliminate drowsiness and maintain stamina.

\section{Target Market for Mangsi Coffee Ground Coffee Products}

According to Kasali (2000), the product of targeting is the target market, which is one or several market segments that will be the focus of marketing activities. Two potential segments can be the target market for Mangsi Coffee ground coffee. The potential segments according to the results of data processing are selected based on psychographics and consumer behavior. The characteristics of respondents who are the target market are men who are adults, have a higher education level (latest education), and work as employees with monthly expenses above the Denpasar City Minimum Wage in 2019 (IDR 2,553,000). These characteristics were chosen because the segment is consumptive to Mangsi Coffee products. Mangsi Coffee consumers based on psychographic segmentation tend to choose quality products and make the habit of consuming coffee a trend and lifestyle while
Mangsi Coffee consumers based on behavior segmentation, tend to choose products according to benefits.

\section{The Positioning of Mangsi Coffee Ground Coffee}

Positioning is "the act of designing the company's offering and image so that they occupy a meaningful and distinct competitive position the target customer mind", it means the actions taken by marketers to create product images and things they want to be offered to its market is successful in obtaining a clear and meaningful position in the minds of its target consumers (Kotler in Kasali, 2000). The goal is to survive or excel in competition. Competitor product comparisons from Mangsi Coffee ground coffee include ground coffee from the brand of Kupu-Kupu Bola Dunia, Banyuatis dan Setia Bali. These three products were chosen with the consideration that the product is similar, namely Bali ground coffee, the three products have both entered the minimarket, and the price of the competitive product ranges from IDR 10,000 - IDR 25,000.

Multidimensional Scaling (MDS) analysis is used to determine the similarity of competitors' products. Multidimensional Scaling (MDS) analysis relates to a perceptual map to describe how the positioning of Mangsi Coffee ground coffee is compared to its three competitors, namely the ground coffee of Kupu-Kupu Bola Dunia, Banyuatis and Setia Bali. Image 1. Below is the result of the MDS map from the position of the Mangsi Coffee ground coffee. It can be explained that the Mangsi Coffee ground coffee product is not in one quadrant with its three competitor products. The map shows the four products are in different quadrants. Products that are in one quadrant and close to each other are two very tightly competitive products (Kasali, 2000).

The results of the correspondence analysis are based on the map of the consumer's perception attribute column. 


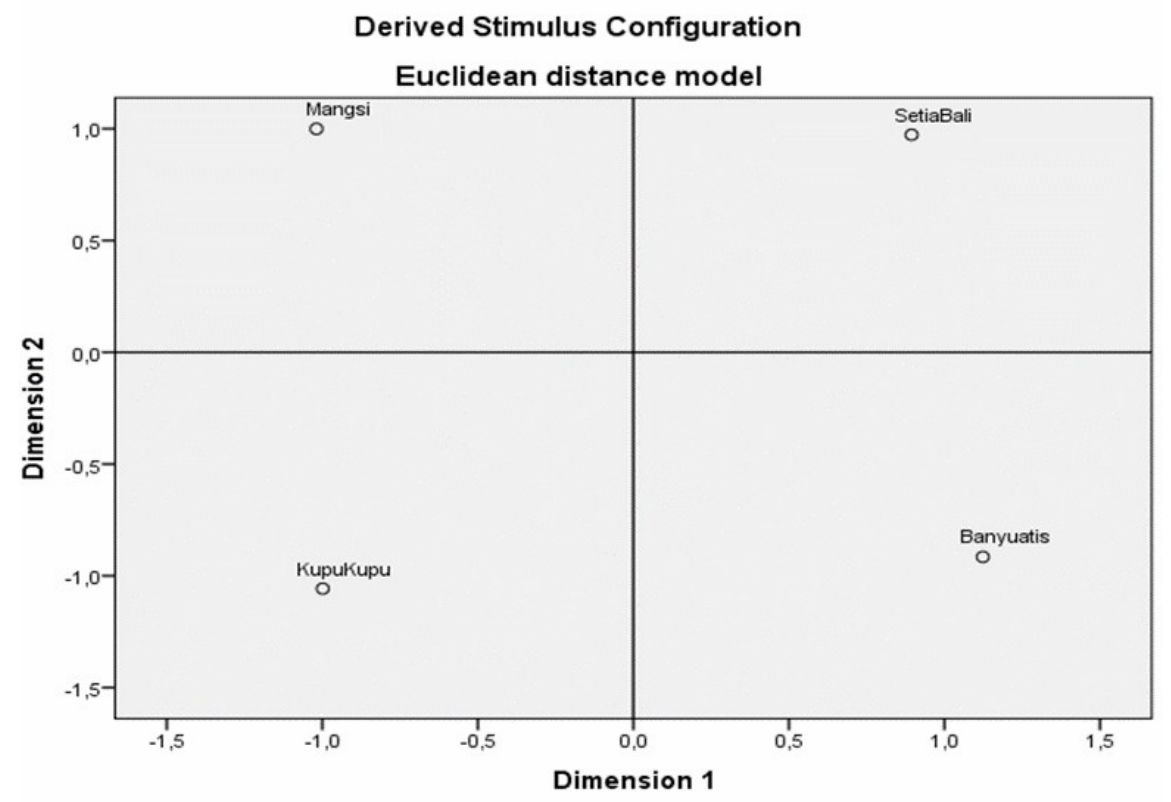

Figure 1. Map of Similarities to Mangsi Grounded Coffee based on Consumer Perceptions Source: Primary Data, 2019

Quadrant I (top left), namely the attributes of price, aroma and price discounts are viewed equally by respondents. Quadrant II (top right), namely the advertising attribute has different values in the view of consumers and there are no attributes that accompany it. Quadrant III (bottom right), consumers have different views on packaging assessments. Finally, in quadrant IV (bottom left) the attributes of impression, outlet and quality are considered the same by the respondent.

The results of the correspondence analysis by combining the attribute column map with the ground coffee product column map can be seen in Figure 2.
Quadrant I (top left) is Setia Bali ground coffee. Setia Bali ground coffee has a close relationship with price, discount, and aroma attributes. This shows that Setia Bali ground coffee is close to consumers who are loyal to using the product through its distinctive aroma and lower price than the three competing products.

1. Quadrant II (top right) is a Banyuatis ground coffee product. Banyuatis ground coffee has a close relationship with advertising attributes. This shows that Banyuatis' ground coffee products are strong in promoting their products through advertisements.

Table 1. Ground Coffee Product Attributes per Quadrant According to Line Score

\begin{tabular}{cc}
\hline Quadrant & Attributes \\
\hline I (Top Left) & Price \\
& Smell \\
II (Top Right) & Discount \\
III (Bottom Right) & Advertising \\
IV (Bottom Left) & Packaging \\
& Impression \\
& Outlet \\
\hline
\end{tabular}

Source: Modified by Reseracher from Various Research, 2019 


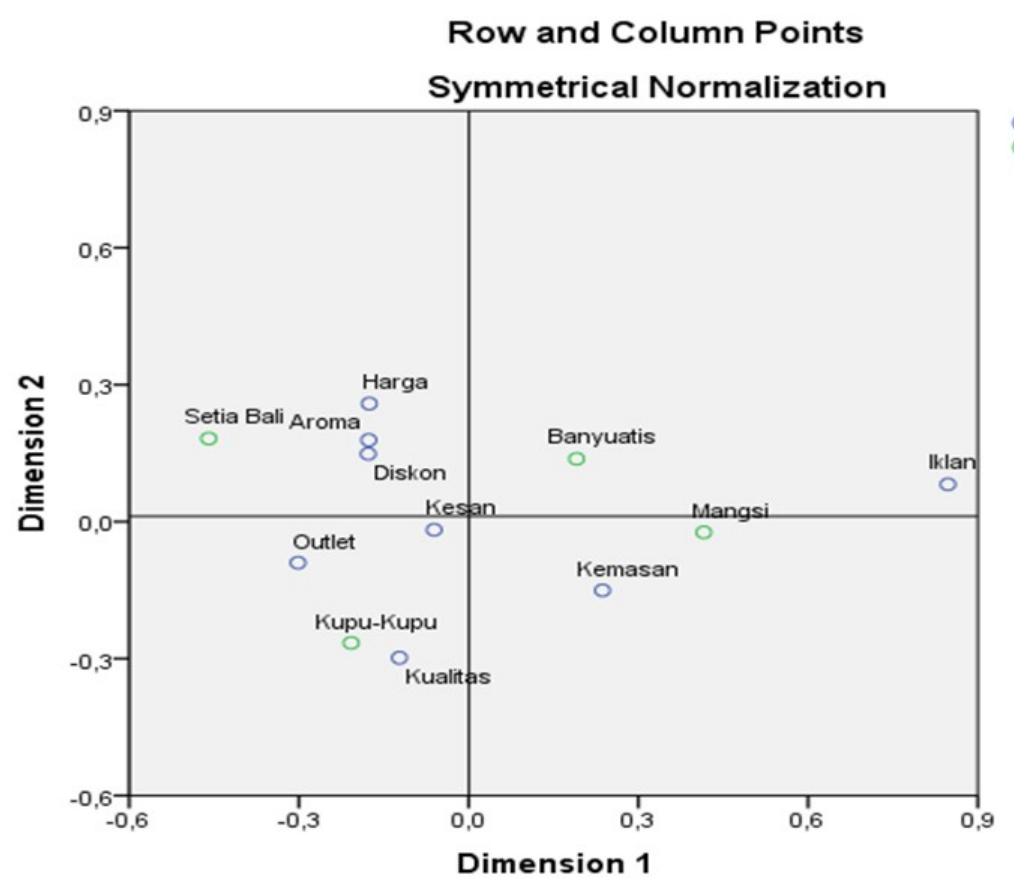

Figure 2. Columns Map of Attribute with Column Map of Grounded Coffee Products Source: Primary Data, 2019

2. Quadrant III (bottom right) is the ground coffee product of Mangsi Coffee. Mangsi Coffee ground coffee has a close relationship with packaging attributes. Therefore, Mangsi Coffee ground coffee has advantages in terms of packaging for product branding. This strategy is a positioning based on product differences. Marketers can show their market where the unique product feature is (Kasali, 2000).

3. Quadrant IV (bottom left) is ground coffee of the Kupu-Kupu Bola Dunia. The ground coffee of Kupu-Kupu Bola Dunia has a close relationship with the attributes of outlet, impression/image and quality. This means that the ground coffee of the KupuKupu Bola Dunia is easier to obtain (more outlets than the three competitors), the impression/image tends to be positive, and the quality is considered positive (higher quality) than the three competitors (Mangsi, Banyuatis and Setia Bali).

\section{Strategy to Increase Sales of Mangsi Coffee Ground Coffee Products}

The strategy to increase sales of Mangsi Coffee ground coffee products is conducted by positioning it to enter the consumer's brain. Several strategies that can be considered to increase sales are to improve and maintain product quality, maintain packaging attributes as a product advantage, offer affordable prices and provide discounted prices, and increase promotion through digital marketing. Previously, Mangsi Coffee had used social media as a promotional medium. Therefore, by optimizing promotions using Instagram Ads and Facebook Ads to select segments and targets that refer to research results, the advantages of the products offered can match the target.

\section{CONCLUSION}

Based on the results of the research conducted, it can be concluded that:

1. Market segmentation of Mangsi Coffee ground coffee based on consumer characteristics is male who is mature, highly educated (latest education), works as an employee with monthly expenses above the Denpasar City Minimum Wage in 2019 (IDR 2,553,000). 
2. The potential segment as a target market for Mangsi Coffee ground coffee is Mangsi Coffee consumers based on a psychographic segmentation that tends to consume coffee as a trend and lifestyle, while Mangsi Coffee consumers based on consumer behavior segmentation tend to choose products according to benefits.

3. The positioning of Mangsi Coffee ground coffee compared to its competitors is superior in terms of packaging attributes.

4. The strategy to increase sales of Mangsi Coffee ground coffee products is conducted by improving and maintaining product quality, maintaining packaging attributes as product advantages, offering affordable prices and providing discounted prices, and increasing promotion through digital marketing.

Based on the research conducted, the suggestions by the authors are as follows:

1. The importance of companies paying attention to segmenting, targeting, and positioning to be able to focus on achieving company goals and survive in the tough market competition. The strategy to increase sales can be conducted by adjusting the results of studies in research and the conditions of the Mangsi Coffee company so that the company may decide policies that are following the company's goals.

2. Research needs to be continued by further researchers by developing other marketing strategies so that they may assist the company in making policies for the company's progress.

\section{REFERENCES}

Ardana, I. K. 2017. Kinerja kelembagaan perlindungan indikasi geografis kopi kintamani. Agricore: Jurnal Agribisnis dan Ekonomi Pertanian 2(1): 242-246.

Dewi, Y. 2017. Strategi segmenting, targeting, dan positioning pemasaran beras merah organik Jatiluwih Bali di Provinsi Bali. JAA: Jurnal Agribisnis dan Agrowisata 6(4): 596-605.
Halodoc, 2018. Banyak deadline, ini manfaat minum kopi sebelum kerja. https://www.halodoc.com/banyakdeadline-ini-5-manfaat-minum-kopisebelum-kerja. Accessed on 15 January 2020.

Herlyan, E. 2012. Fenomena coffee shop sebagai gejala gaya hidup baru anak muda. Jurnal THAQAFIYYAT 13(1): 187-204.

Kasali, R. 2000. Membidik Pasar Indonesia Segmentasi, Targeting dan Positioning. Jakarta. Gramedia.

Kementan, 2016. Outlook kopi komoditas pertanian subsektor perkebunan. Pusat data dan Sistem Informasi Pertanian Sekretariat Jendral - Kementrian Pertanian.

Kotler, P. and G. Armstrong. 2001. Prinsip Prinsip Pemasaran. Jakarta. Erlangga.

Lestari, W. 2017. Peningkatan penjualan produk brem Bali Dewi Sri Pada PT Hatten Bali berdasarkan strategi segmenting targeting dan positioning di Bali. JAA: Jurnal Agribisnis dan Agrowisata 6(3): 356-367.

MPIG (Masyarakat Perlindungan Indikasi Geografis - Kopi Kintamani). 2007. Buku persyaratan indikasi geografis kopi arabika Kintamani Bali.

MPIG (Masyarakat Perlindungan Indikasi Geografis - Kopi Pupuan). 2016. Buku persyaratan indikasi geografis kopi robusta Pupuan Bali.

Rahardjo. 2012. Panduan Budidaya dan Pengolahan Kopi Arabika dan Robusta. Bogor. Penebar Swadaya. 